\title{
In Search of the Ideal Energy Mix for Indonesia: Renewable Energy and Energy Security
}

\author{
Darman Mappangara ${ }^{1}$ and Ari Warokka ${ }^{2}$ \\ ${ }^{1}$ Doctoral Program in Business Management, Padjajaran University, Indonesia \\ ${ }^{2}$ Centro Internacional "Carlos V", Universidad Autonoma de Madrid, Spain
}

Correspondence should be addressed to: Ari Warokka; ari.warokka@gmail.com

Received date: 8 October 2014; Accepted date: 12 December 2014; Published date: 21 July 2015

Copyright (C) 2015. Darman Mappangara and Ari Warokka. Distributed under Creative Commons CCBY 4.0

\begin{abstract}
The significance of renewable energy and energy security to Indonesia's agenda on energy security and its sustainability is the main focus of this paper. Specifically, it studied the current status of both issues and discoursed the opportunities and challenges in the further expansion and utilization of renewable energy. The study explored and employed secondary data from the Indonesian Ministry of Energy and Mineral Resources, World Bank, International Energy Agency, World Energy Council, and ASEAN Centre for Energy. It used also some relevant informative reports to support the analysis. The major findings are: [1] renewable energy performs an important role for an increasingly significant share of Indonesia's energy mix for power generation in 2025 vision and [2] geothermal and hydropower are the main renewable-energy sources. Nevertheless, rather complex institutional and stakeholder arrangements in the energy sector have impeded the promotion of renewable energy. This study contributes to building the existing knowledge base on Indonesia's renewable energy.
\end{abstract}

Keywords: energy mix, energy security, renewable energy, Indonesia

\section{Introduction}

The ironical decision that the Indonesian government should take in 2008 to withdraw its membership from OPEC (Organization of the Petroleum Exporting Countries) had changed the 47-years-oil exporter to become a net importer of oil. It is because Indonesia has seen its stagnated and depleted oil production. At the same time, the volatile price of oil has forced the government to reduce the energy subsidies through moderating its heavy reliance on oil-based power production (Asian Legal Business, 2010).

The decision reflects the current condition that is happening in the world energy landscape. Unstable oil price, depleting process of fossil energy resources, climatechange problems, and degraded and polluted environment due to the continued use of hydrocarbon deposits obliged both developed and emerging countries to look for and foster sustainable alternative energy sources. It becomes a continuing challenge to almost a fifth of the world's 
population in accessing modern energy - a basic form of energy security (IEA, 2013).

Renewable energy, which is known for hydro, wind, geothermal, and solar-based energy, has become a main focus of any country's energy agenda as countries continue to diversify their energy mix to solve the classic "energy trilemma" security, sustainability, and economic prosperity. There are still challenges and gaps needed to be addressed for RE's further development and deployment, while it's potential contribution is promising. The renewable energy optimization is expected to give a sustained country's competitiveness.

Indonesia is in search of its ideal energy mix. The government, by enacting a 2006 presidential decree, committed itself to increase the portion of renewable energy to ensure 15 per cent of the primary energy supply by 2025 , up from 4.3 per cent in 2005 (IEA, 2011a; 2011b). To implement the targets, the government decreed the Energy Law of 2007. However, as of 2010, the progress was relatively stagnant, in which renewable energy, including hydropower, still made up less than 5 per cent of the national primary energy mix (MERM, 2011).

At the same time, the burden of national budget on subsidized fuel, especially for the transportation sector, is getting bigger and relatively uncontrollable. The volatile oil price, higher consumption, and Rupiah depreciation are the triggers (Jakarta Post, 2014). The increasing number of oil-fueled vehicles and the inefficient and highly consumptive behavior of mostly oil-based energy users, such as households, industry, commercials, and power plants, have also drained extra budget for at least $\mathrm{Rp} 42$ trillion in the first semester of 2014. As an oil importer, Indonesia's energy security depends on the oil-consumption behavior and the oil-market price (MEMR, 2013). Any energy mismanagement will threaten the national economic prosperity (the last of the energy trilemma). Therefore, renewable-energy development and energy security enhancement are the sine qua non for maintaining and accelerating Indonesia's economic growth.

This paper provides a summary and an analysis of Indonesia's energy mix strategy and scenario, its opportunities and challenges, and the evolving context of its energy security.

\section{Indonesia: An Overview}

As an archipelago country, which has 13,466 islands, a territorial area of $7,788,810$ square $\mathrm{km}$, and estimated inhabitants of over 240 million, Indonesia is the world's fourth most populous country and known as one of the richest diversified-natural resources' countries (MEMR, 2013).

The hydrocarbon sector became a main engine of Indonesia's economy since the Dutch discovered it in 1885 . However, its contribution is declining in the last decade. This sector, which mainly consists of oil and gas industry and refining, contributed approximately 7 percent to the growth domestic product (GDP) in 2010 (BPS, 2011). Even though Indonesia is not an OPEC member, its production contributed for roughly 1 percent of the world's daily production of liquid fuels. It ranked 20th among the world oil producers and 21st for crude oil and condensate production in 2011.

Indonesia GDP growth rate has been experiencing a positive trend for the last 12 years, while it descended to $4.6 \%$ in 2009 as the impact of the global economic crisis 2008 (Figure 1). The same pattern happens as well for GDP per capita. However, the encouraging tendency of GDP growth is in parallel with the increasing intensity ratio of the final energy consumption. Intensity ratio is the whole sources of energy (i.e. solid fuels, oil, gas, and renewable sources) divided by GDP per capita. In the last decade, the growth pace of the total energy consumption (in average $4.05 \%$ yearly) is relatively similar with the GDP growth one (Figure 2). Meanwhile, the growth of the primary energy supply per capita (PES per capita) in average is $4.37 \%$ per annum. Even though, Indonesia has advantages in 
sustained economic growth, improved the living standards, and a demographic bonus (i.e. increased labor force and reduced unemployment rate), it is still facing a serious challenging energy demand in the foreseeable

future.

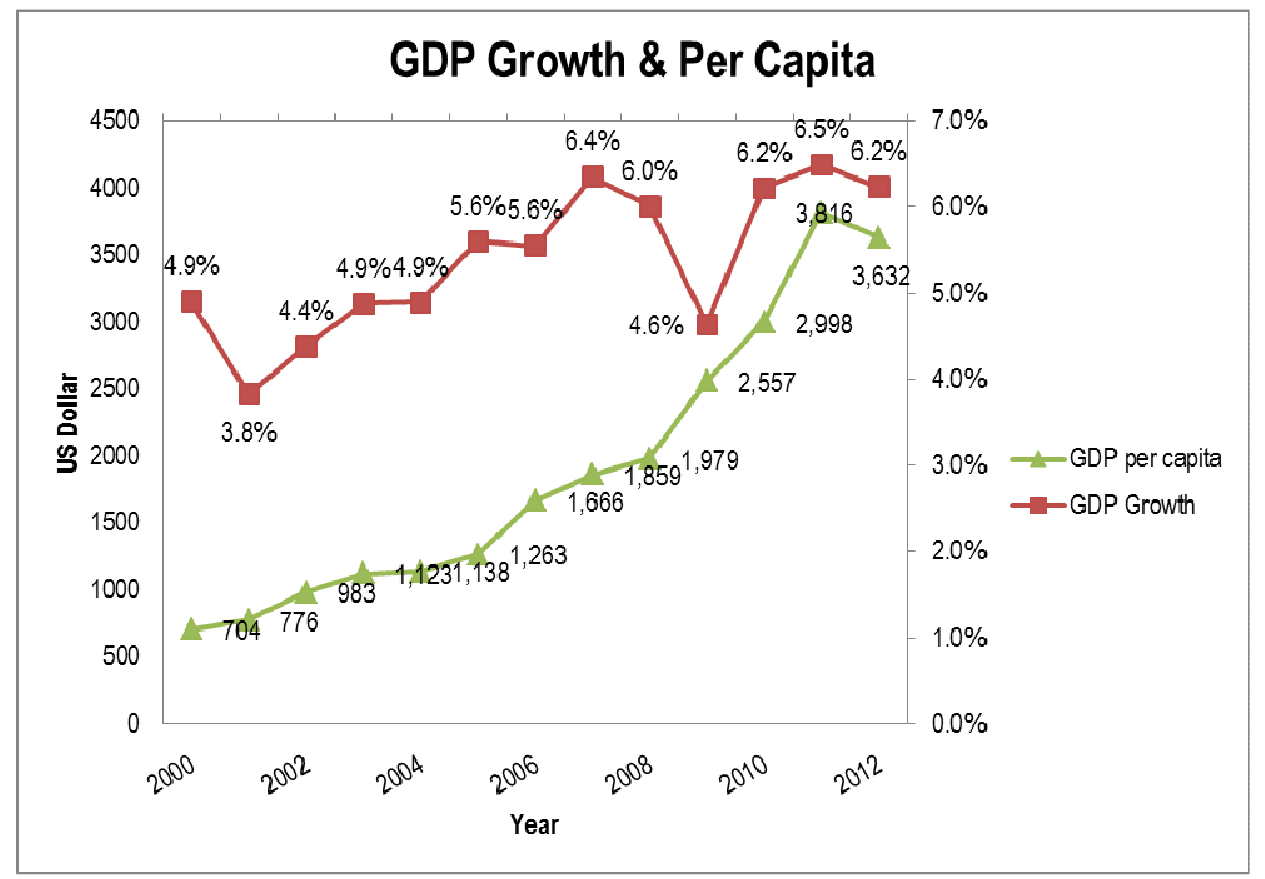

Figure 1: GDP Growth and GDP per capita

Source: Elaborated data from Center for Data and Information on Energy and Mineral Resources (CDIEMR, 2013)

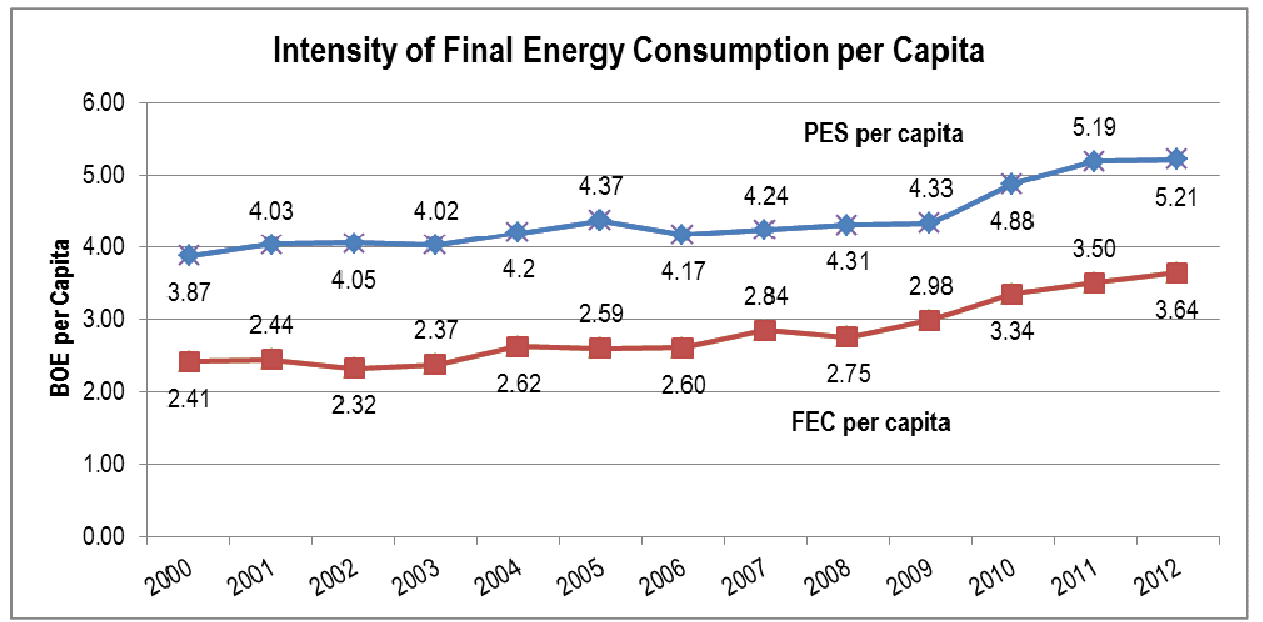

Figure 2: Intensity of Final Energy Consumption per capita

Source: Elaborated data from Center for Data and Information on Energy and Mineral Resources (CDIEMR, 2013) 
It means that Indonesia will continuously deal with the quest of reliable energy security. It also becomes a strategic measure for Indonesia's capability in responding to the dynamic change of global energy (i.e. external side) and building its independency to secure energy accessibility (i.e. internal side). The Ministry of Energy and Mineral Resources (2013) predicted that the security buffer between national energy supply and demand would be smaller and threatening its energy security if there was no comprehensive energy management. It needs serious efforts to find new energy sources, reduce the heavy reliance on oil- based energy, and create a sustainable energy mix.

\section{Indonesia Energy Mix Scenario}

Based on Surono's report (2014), Indonesia's oil reserve is only sufficient for 23 years. Meanwhile, for natural gas and coal, Indonesia still has energy reserve for 50 years and 80 years, respectively. World Outlook Energy (2014) affirms this current situation revealing an extreme difference share between oil and coal reserves (Figure 3). It challenges the Indonesian government to explore and find other viable energy sources.

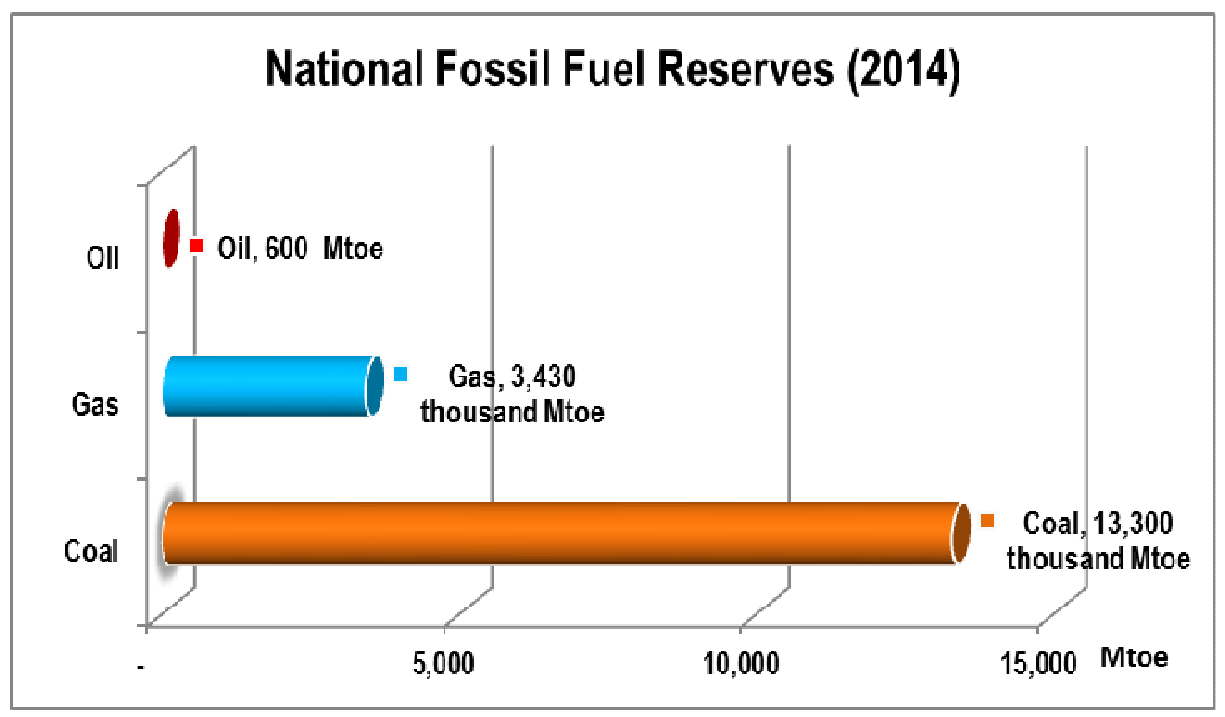

Figure3: National Fossil Fuel Reserves as of 2014

Source: Elaborated data from MEMR (2013) and World Outlook Energy (2014)

As of 2014, Indonesia still faces limited access to energy. Electrification ratio, which measures the percentage of population with access to power energy, is still $76.56 \%$ in 2012 (MEMR, 2014). It means that there are $23.44 \%$ of inhabitants living without electricity; especially those who are in remote areas and outer islands. Oil dominates the energy mix share, and the use of renewable energy is less than $5 \%$ (Figure 4). In 2006, the Indonesian government placed prominence policy on developing biofuels and geothermal energy by enacting the Presidential Decree No. 5. It sets up, specifically, each five per cent of the total primary energy supply should come from geothermal and biofuels by 2025. It also determines the quota for renewable energy and percentage ceiling for coal, natural gas, and oil in the energy mix in which the share of oil-based energy should be less than 60 per cent.

In 2014, the House of Representatives approved a new government regulation on energy policy. This national energy policy (NEP), basically, is a definitive policy enhancing Indonesia's energy security mix in which the share of renewable energy is bigger than before. Specifically, it plans to 
reduce gradually costly fuel and electricity subsidies over the decade. As a consequence, it would be an increase in the prices of fuel and electricity that it reflects "the production costs" and adds environmental conservation and investment sustainability. It also explicitly plans to stop exporting coal and gas by 2025 (The Jakarta Globe, 2014).

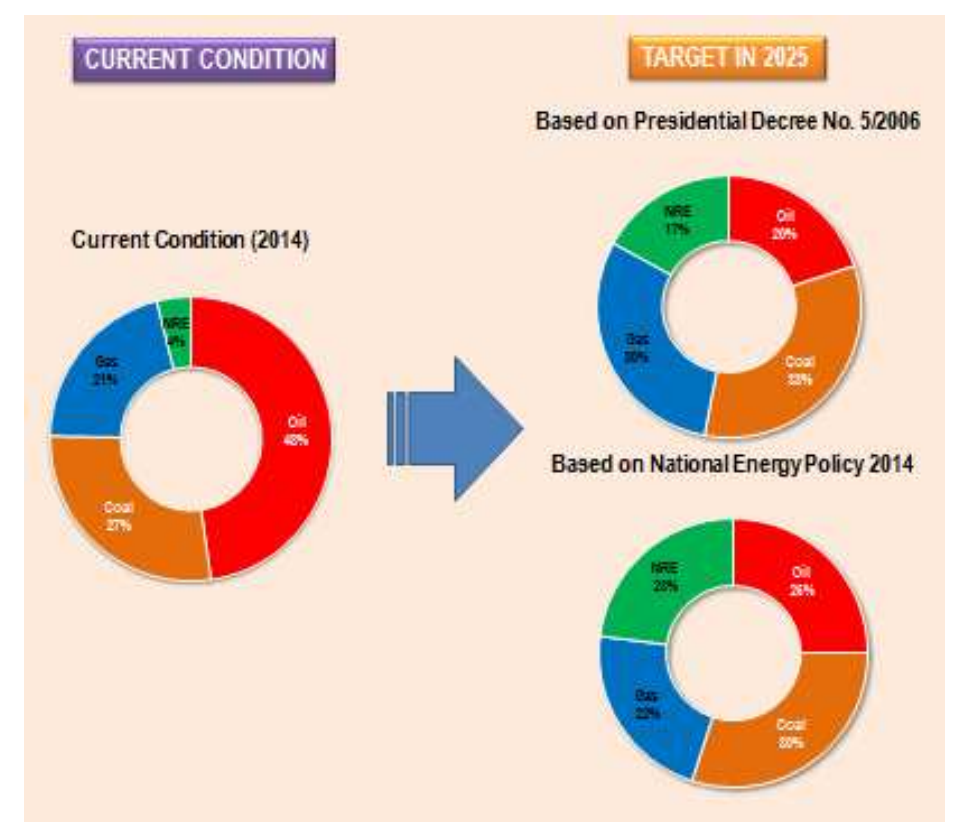

Figure 4: National Fossil Fuel Reserves as of 2014

Source: Elaborated data from MEMR (2014)

Figure 4 shows the share of renewable energy is $23 \%$ by 2025 , an increase of $6 \%$ from Presidential Decree's target. Both regulations (PD 2006 and NEP 2014) affirm to reduce energy elasticity to below 1 and improve energy infrastructure. The government is implementing a policy paradigm shift in its energy security system, from supply side policy (SSP) to demand side policy (DSP). At SSP, the government managed energy supply security in the forms of energy exploration and optimization. Meanwhile, at DSP, the government encourages society awareness to do energy diversification and conservation (Figure 5). 


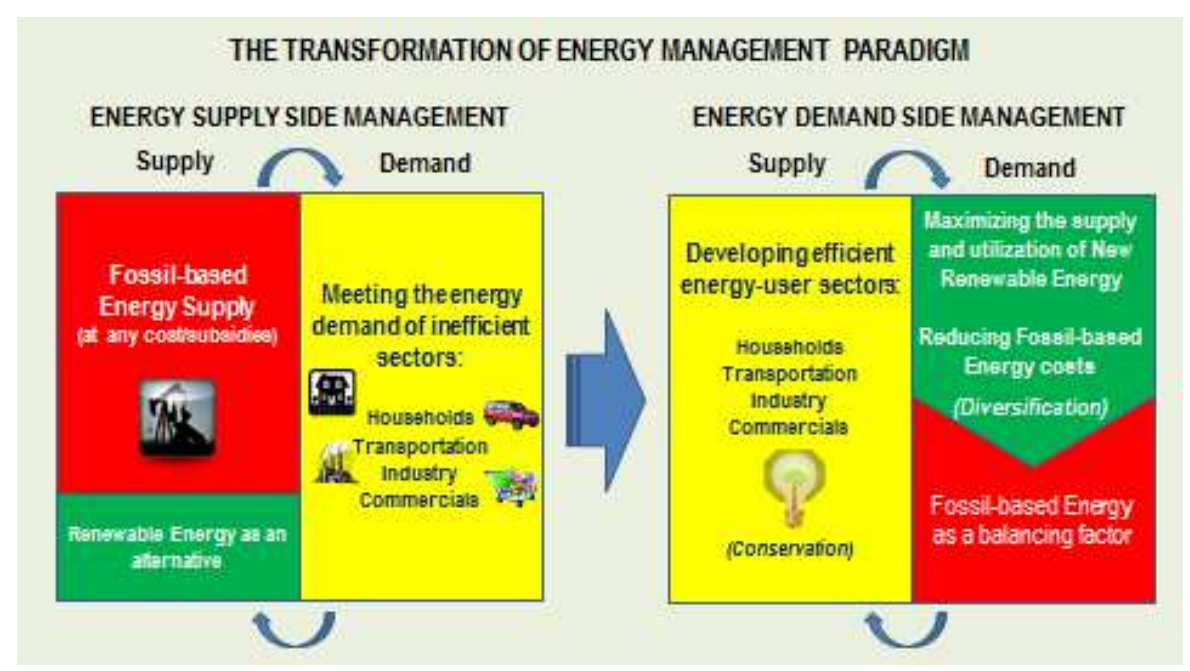

Figure 5: The Transformation of Energy Management Paradigm

Source: Elaborated data from Presidential Decree No. 5/2006 and NEP 2014

One of the paradigm shift's consequences is the market-based energy pricing. It is to reduce gradually energy subsidies in which the government applies energy source's diversification and energy conservation policies simultaneously. The paradigm change is to ensure the Indonesia energy mix scenario in 2025 (Figure 6). The roadmap reveals that the deployment and development of renewable energy are crucial aspects of the Indonesian government's strategy on energy security.

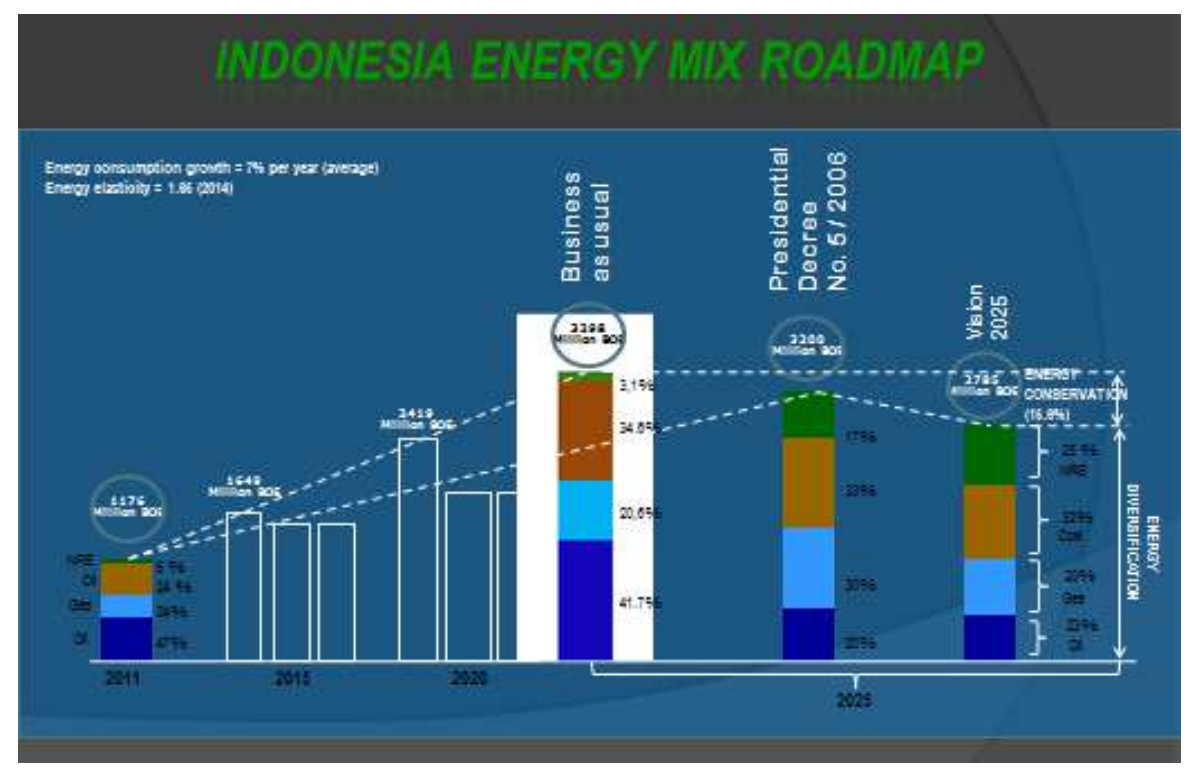

Figure 6: Indonesia Energy Mix Roadmap

Source: Elaborated data from Presidential Decree No. 5/2006 and NEP 2014

Since the shift of Indonesia's status, from an oil exporter to the net oil importer, its energy security is inevitably at risk to oil price fluctuations and geopolitical dynamics affecting the oil-exporting countries. It threatens also the energy 
sustainability concerning climate change, environmental degradation, and pollution. Those major issues are the drivers for Indonesian government to harness and optimize viable alternative energy sources.

The parliament ratification on the National Energy Policy 2014 (January 28) has given a decisive framework for the fast-tracked development and expansion of renewableenergy resources. It also outlines a key program to increase all the potential renewable-energy (RE) utilizations. Specifically, NEP arranges for the overall strategic policy guidelines for the RE industry, sets RE targets, and addresses issues related to the provision of RE and its impacts (PP, 2014). Table $1 \mathrm{a}$ and Table $1 \mathrm{~b}$ outline the National Energy Mix Projection in percentage and energy unit equivalent. By per energy unit equivalent basis, Indonesia seeks to increase its hydropower and geothermal capacity by $1000 \%$, deliver additional 25 Mtoe biomass-biofuel capacity, attain solar power capacity of four Mtoe, and pursue an optimization of biomass from waste (for electricity) by nine Mtoe, all in 2015. It will reduce significantly the share of non-renewable energy (NRE) by $10.2 \%$ within 10 years. The projection sets a mix of $25.9 \%$ and $74.1 \%$ for RE and NRE by 2025, respectively.

\section{Table 1a: National Energy Mix Projection (2010-2014) in Energy Unit Equivalent}

\begin{tabular}{|c|c|c|c|c|c|c|c|}
\hline \multicolumn{8}{|c|}{ The National Energy Mix Projection (Mtoe) } \\
\hline National Energy Mix Scenario & 2010 & 2015 & 2020 & 2025 & 2030 & 2040 & 2050 \\
\hline Biomass - Biofuel & 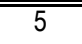 & 10 & 15 & 30 & 40 & 70 & 95 \\
\hline Biomass from waste (for electricity) & - & 1 & 3 & 9 & 20 & 40 & 55 \\
\hline Subtotal of Biomass & 5 & 11 & 18 & 39 & 60 & 110 & 150 \\
\hline Geothermal & 3 & 9 & 15 & 30 & 40 & 65 & 85 \\
\hline Hydro Power & 1 & 2 & 5 & 11 & 15 & 20 & 24 \\
\hline Ocean Power & - & - & 0,5 & 1 & 1,4 & 3 & 5 \\
\hline Solar Power & - & 0,5 & 2 & 4 & 6 & 14 & 18 \\
\hline Other Renewable Energy Resources & - & 0,2 & 1 & 1,5 & 2 & 4 & 5 \\
\hline Subtotal of Non Biomass Renewable Energy & 4 & 12 & 24 & 48 & 64 & 106 & 137 \\
\hline Subtotal of Renewable Energy & 9 & 23 & 42 & 87 & 124 & 216 & 287 \\
\hline Total of New Renewable Energy & 9 & 23 & 44 & 99 & 148 & 276 & 387 \\
\hline Oil & 79 & 83 & 85 & 90 & 93 & 125 & 162 \\
\hline Gas & 32 & 42 & 55 & 75 & 90 & 120 & 140 \\
\hline Coal & 39 & 67 & 107 & 117 & 149 & 222 & 291 \\
\hline New Energy (nuclear, etc.) & - & - & 2 & 12 & 24 & 60 & 100 \\
\hline TOTAL Energy & 159 & 215 & 290 & 380 & 480 & 740 & 980 \\
\hline
\end{tabular}


Table 1b: National Energy Mix Projection (2010-2014) in Percentage

\begin{tabular}{|l|c|c|c|c|c|c|c|}
\hline \multicolumn{7}{|c|}{ The National Energy Mix Projection (\%) } \\
\hline National Energy Mix Scenario & $\mathbf{2 0 1 0}$ & $\mathbf{2 0 1 5}$ & $\mathbf{2 0 2 0}$ & $\mathbf{2 0 2 5}$ & $\mathbf{2 0 3 0}$ & $\mathbf{2 0 4 0}$ & $\mathbf{2 0 5 0}$ \\
\hline \hline Biomass - Biofuel & 3,1 & 4,7 & 5,2 & 7,9 & 8,3 & 9,5 & 9,7 \\
\hline Biomass from waste (for electricity) & 0,0 & 0,5 & 1 & 2,4 & 4,2 & 5,4 & 5,6 \\
\hline Geothermal & 1,9 & 4,2 & 5,2 & 7,9 & 8,3 & 8,8 & 8,7 \\
\hline Hydro Power & 0,6 & 0,9 & 1,7 & 2,9 & 3,1 & 2,7 & 2,4 \\
\hline Ocean Power & 0 & 0 & 0,2 & 0,3 & 0,3 & 0,4 & 0,6 \\
\hline Solar Power & 0 & 0,2 & 0,7 & 1,1 & 1,3 & 1,9 & 1,8 \\
\hline Other Renewable Energy Resources & 0 & 0,1 & 0,3 & 0,4 & 0,4 & 0,5 & 0,5 \\
\hline New Renewable Energy Mix & $\mathbf{5 , 7}$ & $\mathbf{1 0 , 6}$ & $\mathbf{1 5}$ & $\mathbf{2 5 , 9}$ & $\mathbf{3 0 , 9}$ & $\mathbf{3 7 , 3}$ & $\mathbf{3 9 , 5}$ \\
\hline Oil & 49,7 & 38,6 & 29,3 & 23,7 & 19,4 & 16,9 & 16,5 \\
\hline Gas & 20,1 & 19,5 & 19 & 19,7 & 18,8 & 16,2 & 14,3 \\
\hline Coal & 24,5 & 31,3 & 36,9 & 30,7 & 31 & 30 & 29,7 \\
\hline New Energy (nuclear, etc.) & 0 & 0 & 0,7 & 3,2 & 5 & 8,1 & 10,2 \\
\hline Non New Renewable Energy Mix & $\mathbf{9 4 , 3 0}$ & $\mathbf{8 9 , 4 0}$ & $\mathbf{8 5 , 0 0}$ & $\mathbf{7 4 , 1 0}$ & $\mathbf{6 9 , 1 0}$ & $\mathbf{6 2 , 7 0}$ & $\mathbf{6 0 , 5 0}$ \\
\hline \hline
\end{tabular}

While Indonesian government has enacted laws, implemented supportive policies, and set targets, there remain intensive debates on how to optimize its huge potential renewable energy for securing energy in the future.

\section{Renewable Energy and Energy Security In Indonesia}

In its search of sustainable energy mix, the Indonesian government sees remarkable potential in renewable energy. Indonesia has a rich endowment of largely undeveloped renewable-energy resources, such as hydropower and geothermal-based energy. World Energy Council (2013) reports that having an estimated energy of 2150 TWh/year, Indonesia is the thirdlargest in Asia for theoretical hydro potential. However, it is only $10 \%$ of the technically feasible potential of 400 TWh/year (Figure 7) which is considered to be economically exploitable. It means there are 40 TWh/year potentially available. Meanwhile, average annual hydro output is about 12.5 TWh, indicating the evident scope for further development within the feasible potential. Hydro presently contributes roughly $8 \%$ of Indonesia's electricity supply (WEC, 2013).

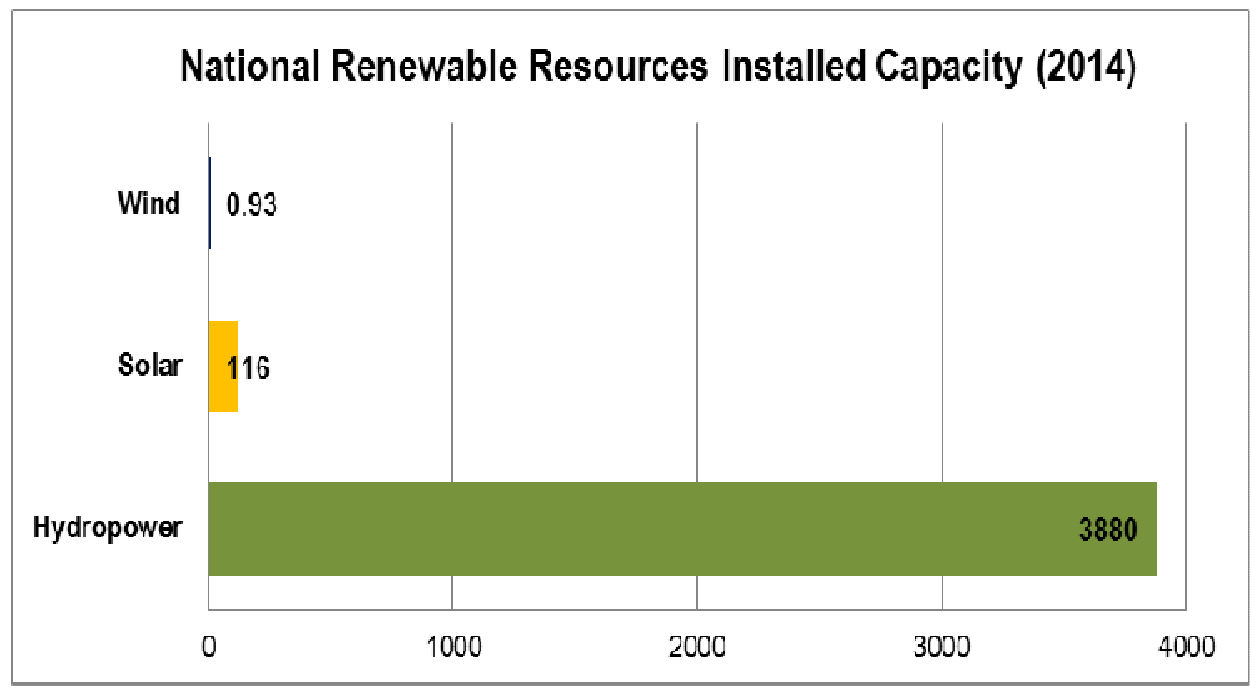

Figure 7: National Renewable Resources Installed Capacity Source: Elaborated data from CDI-EMR (2013) and WEC (2014) 
Besides accelerating the potential energy of hydropower, Indonesia takes the view that it is essential to harness the enormous geothermal resource at its disposal. Having a national geothermic at $27.67 \mathrm{GWe}$, in the Government's National Energy Management Blueprint 2005-2025, it targets 9500 MWe capacity by 2025 .

This target is really challenging due to Indonesia only realizes a tiny fraction of its geothermal potential. By the end of 2008, Indonesia installed a total of $1054 \mathrm{MWe}$ geothermic capacity, of which some $95 \%$ was based on the islands of Java and Bali. Due to the limited infrastructure investment, the remaining 5\% was located on Sumatera and Sulawesi, even though the Sumatera Island has 50\% geothermal potential. Therefore, to regulate effectively both the upstream and downstream side of the sector and fully optimize this power, in the last few years, the government has passed a raft of laws and regulations.

A planned program of construction will gradually increase the capacity to achieve the target of $50 \%$ of the national electricity demand by 2025 that it will be filled by geothermal power. During the World Geothermal Congress 2010, Indonesia announced its plans to launch a $3997 \mathrm{MWe}$ project to expand the geothermal power. It marked the government's commitment for optimizing its renewable energy.

Another viable energy source is peat. Indonesia has the most extensive peat lands (estimated at $207.000 \mathrm{~km}^{2}$ ) and ranks as the fourth largest in the world. These areas are located largely in the subcoastal low-lands of Kalimantan and Sumatera. However, until now, this potential renewable energy is basically undeveloped. It is only a small peat-fired power plant operating in southern Sumatera.

Referred to WEC's Sustainability Index 2014, which evaluates how well a country's balance on the three often conflicting goals of energy sustainability (i.e. energy security, energy equity, and environmental sustainability), Indonesia ranks 73rd among 129 countries. The best score on energy security ("A" score) reflects a very high performance. Meanwhile, the other scores: B, C, and D, are for good, mediocre, and poor performance, respectively. Indonesia's ACD-score reveals that the government has been successful in securing its energy, performed middling in building strong social equity, and failed to mitigate effectively the environmental impact (Table 2). These mediocre and poor performances are related to the dynamic political and economic situation in the last three years.

Table 2: Indonesia's Energy Sustainability Index

\begin{tabular}{|c|c|c|c|c|c|c|}
\hline \multicolumn{7}{|c|}{ Energy Sustainability Index Rankings } \\
\hline \multicolumn{7}{|c|}{ Indonesia = $73(\mathrm{ACD})$} \\
\hline & & 2011 & 2102 & 2013 & Trend & Score \\
\hline \multicolumn{2}{|c|}{ Energy Performance } & 89 & 87 & 68 & ( & \\
\hline 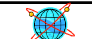 & Energy Security & 39 & 37 & 17 & $\uparrow$ & $\bar{A}$ \\
\hline Nixil & Social Equity & 93 & 94 & 83 & $\uparrow$ & C \\
\hline$\theta$ & Environmental Impact Mitigation & 108 & 109 & 104 & $\uparrow$ & D \\
\hline \multicolumn{2}{|c|}{ Contextual Performance } & 69 & 71 & 72 & $\downarrow$ & \\
\hline & Political Strength & 88 & 92 & 95 & $\downarrow$ & \\
\hline & Societal Strength & 74 & 82 & 82 & $\rightarrow$ & \\
\hline 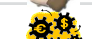 & Economic Strength & 50 & 41 & 42 & $\downarrow$ & \\
\hline \multicolumn{2}{|c|}{ Overall Rank } & 83 & 85 & 73 & $\uparrow$ & \\
\hline
\end{tabular}

The Indonesian government's strong concern on securing energy reflects its main policy to fuel economic growth sustainably. The government is aware that 
energy must be accessible and affordable at all strata of society. At the same time, the impact of energy production and energy use (especially from non-renewable energy sources) on the environment needs to be lessened. However, the energy sustainability index also demonstrates some challenges that the Indonesian government should face and manage its renewable-energy sources effectively and strategically.

\section{Indonesia's Challenges to Renewable Development}

One of the unfavorable stances for Indonesia's RE development is its market energy, which is a rigid and oligopolistic structure. A dominant few players and heavily government-regulated markets are the key features. This is an inheritance of a long history of having governmentcontrolled enterprises with monopoly rights. Until early 2000, it allowed only government-controlled companies to operate and provide energy products for each sub-sector of gas, oil and electric power. There were limited or even noparticipations of private companies for supplying contractual works (International Energy Agency [IEA], 2008).

However, the Asian financial crisis 1997 has changed the market and put pressure on the government to liberalize and deregulate the industry. It has opened the industry and allowed more players to explore and offer the energy. Nevertheless, the government-controlled companies maintain a dominant position. There are two sub-sectors in the Indonesian oil and gas industry: upstream and downstream sub-sectors. Companies operating in the upstream sector are prohibited from conducting business in the reversed one. Those companies may, however, set up separated-business establishments to operate in each subsector (PWC, 2012). PERTAMINA, the state-owned company responsible for oil and gas production and distribution, before the deregulated Law $22 / 2001$ on oil and gas, used to be the biggest player in the upstream business and also performed as the government representative to assign contract works to other companies. Nowadays, it loses its licensor power.

The Indonesian policy-makers and implementers are rather complex institutional and stakeholder arrangements in the energy sector. At least, there are four government agencies directly involved in formulating or implementing renewableenergy policy at a national level. Meanwhile, local governments and a number of other government agencies are also having influence over either policy or its implementation (Figure 8).

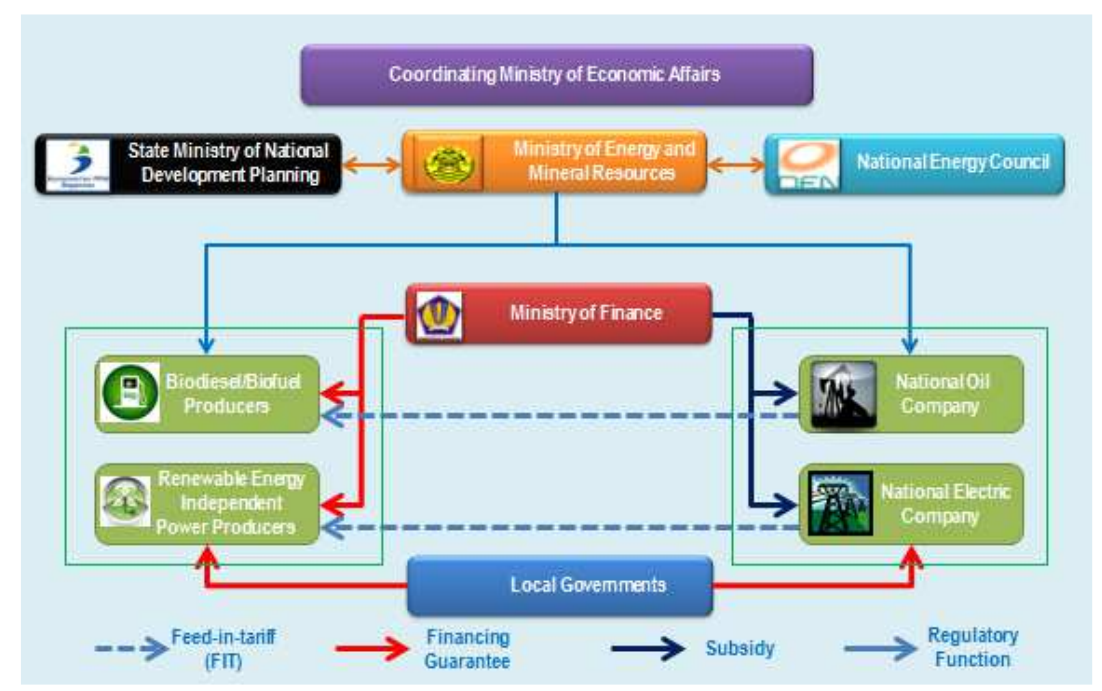

Figure 8: Institutional Framework of Energy Investment Incentives Source: Adapted data from TKN Report (2012) 
There are four major investment incentives for renewable-energy expansion in Indonesia: first, financial inducements, which provide low-rate and guaranteed loans; second, fiscal incentives such as tax exemptions and other tax-related subsidies; third, access to competitive market share; and fourth, market price support and regulation, which provide access to the production and selling of renewable energy above the market prices (TKN Report, 2012). Presidential Decree No. 5/2005 regulates most of these incentives and the implementation of specific schemes as described in Figure 8.

However, mostly the available investment incentives for renewable energy in Indonesia are in the context of development and operational stages of a renewable-energy project. It mainly focuses on providing assistance during the operation's phase of a project. It also contains the government's commitment to provide financial advantages to those companies which are actually producing renewable energy. On the other hand, few investment incentives are available at the pre-investment stage, especially for large geothermal power and hydropower projects, where the needs of initial capital are very high. Many incentives in the preinvestment stage are not targeted at renewable-energy development, specifically; instead, they are more generally intended to promote the development of infrastructure. The TKN Report (2012) also discovers that no incentive programs supporting innovation and technology acquisition would promote investment in renewable energy.

Another challenge is lack of coordination between central and regional governments. Since the decentralization process began in 2001, local governments received a transfer of some authority over investment procedures and related government revenue. As a result, regional governments, for instance, hold the right to determine the site of business activities following their provincial development master plan. The problem often arises when investors having secured approvals from the central government will need to reevaluate their plans in order to comply with local governments' requirements, or even totally cancel them (Pambudi, 2006). Those governments may also impede or encourage investment decisions through regional fiscal policies, such as local taxes and levies or subsidies.

Additionally, the current institutional framework reveals as well that a divided stance between government institutions can be one of the most serious impediments to the promotion of renewable energy. For instance, geothermal projects have been stalled due to disagreements between the Ministry of Forestry and the Ministry of Energy and Mineral Resources, while incentives for biofuels remain weak because of disagreements about the fuel's sustainability and its impacts on food markets (TKN Report, 2012).

Finally, until now, the Indonesian government's continuing subsidization of gasoline and under-pricing of electricity generation provides reversed incentives to investment incentives for renewable energy. Those unfavorable issues actually are the government's homework that it should be solved soon to secure energy and its sustainability.

\section{Conclusion}

A dramatic change from an oil-exporter country to a net oil-importer has put Indonesia to reassess its national energy management. The quest of an ideal energy mix to meet the current demand and the future energy sustainability makes the government explore and optimize its huge potential of renewable energy. The Presidential Decree No. 5/2006 and the National Energy Policy 2014 reflect Indonesia's endeavor to implement its energy security policy. It strives to reduce energy elasticity to less than 1 , align with the target of economic growth, and enhance the national energy mix with: oil below $20 \%$, natural gas by $27 \%$, coal to maximum $30 \%$, and the remaining $23 \%$ from new and renewable energy. 
While Indonesia has decreed and employed a set of policies in accelerating the development and advancement of RE, there have been gaps and unfavorable issues between the implementation of policies and putting in place the related mechanisms. A divided stance between government institutions (especially the related ministries) can be one of the most serious impediments to the promotion of renewable energy. A lack of coordination between central and regional governments often creates uncertainty for renewableenergy investments. And few investment incentives that are available at the preinvestment stage have impeded large geothermal power and hydropower projects that need big initial capital. At the same time, the government's continuing subsidization of gasoline provides unfair support to investment incentives for renewable energy.

Therefore, there are some key issues that policy-makers need to continue to focus on: first, removing hydrocarbon energy subsidies; second, intensifying the efforts to increase the use of new and renewable energy. It can be done through research and development, pilot projects, providing various incentives, and green-energy awareness capacity building. Third, it focuses on enhancing the coordination process between central and local government and simplifying the renewable-energy investment process. Finally, it strives to increase energy efficiency and conservation on supply and demand sides.

\section{References}

1. Ardiansyah,F., Gunningham, N. and Drahos, P. (2012), 'An environmental perspective on energy development in Indonesia,' in M. Caballero-Anthony, Y. Chang, \& N.A. Putra (Eds.), Energy and nontraditional security (NTS) in Asia (pp. 89118). SpringerBriefs in Environment, Security, Development and Peace.

2. Asian Legal Business. (2010), 'A Closer Look at the Power Sector in Indonesia: The Latest Initiatives,' May 6. [Online], [Retrieved 9 September 2014), http://asia.legal

business online.com/industryupdates/indonesiasoemadipradjataher/acl oser-look-at-the-power-sector-inindonesia-the-latest-initiatives/45834.

3. Biro Pusat Statistik (Statistic Indonesia). (2011), 'BPS Strategic Data 2011' [Online], [Retrieved 11 September 2014], http://www.bps.go.id/eng/hasil_publikasi /flip_2011/ 1103003/index11.php?pub=Data\%20Strat egis $\% 20 \mathrm{BPS}$.

4. Center for Data and Information on Energy and Mineral Resources (CDI-EMR). (2011). Handbook of energy \& economic statistics of Indonesia. Jakarta: Ministry of Energy and Mineral Resources. [Online], [Retrieved 7 September 2014], http://prokum.esdm. go.id/Publikasi/Handbook\%20of\%20Ener gy\%20\&\%20Economic\%20Statistics\%20of $\% 20$ Indonesia\%20/HANDBOOK\%20ESDM \%202013.pdf.

5. Center for Data and Information on Energy and Mineral Resources (CDI-EMR). (2013). Handbook of energy \& economic statistics of Indonesia. Jakarta: Ministry of Energy and Mineral Resources. [Online], [Retrieved 7 September 2014], http://prokum.esdm. go.id/Publikasi/Handbook\%20of\%20Ener gy\%20\&\%20Economic\%20Statistics\%20of $\% 20$ Indonesia\%20/HANDBOOK\%20ESDM $\% 202013 . p d f$.

6. International Energy Agency (IEA). (2008), 'Energy policy review of Indonesia,' Paris: International Energy Agency. [Online], [Retrieved 7 September 2014] http://www.iea. org/publications/free publications/publication/name,15765,en.h tml.

7. International Energy Agency. (2011a), 'Electricity/Heat in Indonesia in 2008' [Online], [Retrieved 7 September 2014] http://www.iea.org/stats/electricitydata.a sp?COUNTRY CODE=ID.

8. International Energy Agency. (2011b), 'Renewables and Waste in Indonesia in 2008' [Online], [Retrieved 7 September 
2014]

http://www.iea.org/stats/renewdata.asp? COUNTRY CODE=ID.

9. International Energy Agency. (2013), 'World Energy Outlook 2013,' [Online], [Retrieved 7 September 2014], http://www.worldenergyoutlook.org/publ ications/weo-2013/.

10.Jakarta Post. (2014). 'Indonesia warned of subsidy time bomb,' March 28. [Online], (Retrieved 11 September 2014] http://www.thejakartapost.com/news/20 $14 / 03 / 28 /$ indonesia-warned-subsidytime-bomb.html.

11.Ministry of Energy and Mineral Resources. (2008), 'Membangun Ketahanan Energi [Building Energy Security],' Press Release, April 2008. [Online], [Retrieved 9 September 2014], http://www. esdm.go.id/berita/1687-membangunketahanan.

12.Ministry of Energy and Mineral Resources. (2011), 'Towards sustainable energy supply: Indonesia's energy vision 2025,' Renewable Energy Conference: Green Supply for Growing Demand, Jakarta, 24 October 2011. [Online], [Retrieved 9 September 2014] http://indonesien.ahk.de/fileadmin/ahk_in donesien/PAST_EVENTS/RENERGY2011/ MONDAY/1_-

_Ministry_of_energy_and_mineral_resource s.pdf.

13.Pambudhi, P.A. (2006), 'Peraturan Daerah dan Hambatan Investasi,' Jentera 14(4), Pusat Studi Hukum \& Kebijakan Indonesia, Jakarta.

14.Peraturan Pemerintah (PP). (2014). Peraturan Pemerintah Nomor 1 Tahun 2014: Pedoman Penyusunan Rencana Umum Energi Nasional [Government Regulation No. 1/2014: The Guidance for General National Energy Plan]. Jakarta: Ministry of State Secretariat of the Republic of Indonesia.

15.PriceWaterhouseCooper (PWC). (2012), 'Electricity in Indonesia-Investment And Taxation Guide 2011,' Price Waterhouse
Cooper. [Online], [Retrieved 9 September 2014],

http://www.pwc.com/id/en/publications/ assets/Indonesian-Electricity-Guide_ 2011.pdf.

16.Surono. (2014), 'Cadangan minyak Indonesia hanya cukup untuk 23 tahun lagi [Indonesia's oil reserve is only for 23 years more],' [Online], [Retrieved 23 September 2014]

http://www.tribunnews.com/bisnis/2014 /09/14/cadangan-minyak-di-indonesiahanya-cukup-untuk-23-tahun-lagi.

17.The Jakarta Globe. (2014), 'House of representatives passes National Energy Policy,' January 28. [Online], [Retrieved 9 September 2014)

http://thejakartaglobe.beritasatu. com/news/house-of-representativespasses-national-energy-policy/.

18.Trade Knowledge Report (TKN) Report. (2012), 'Investment Incentives for Renewable Energy: Case study of Indonesia,' Winnipeg: International Institute for Sustainable Development (Canada).

19.Tumiwa, F., Lontoh, L., Lang, K. and VisDunbar, D. (2012), 'A citizens' guide to energy subsidies in Indonesia - Update,' International Institute for Sustainable Development (IISD). [Online], [Retrieved 9 September 2014]

http://www.iisd.org/publications /citizens-guide-energy-subsidiesindonesia-update.

20.World Energy Council. (2013), 'World Energy Resources: 2013 Survey,' London: World Energy Council.

21.World Energy Council. (2014), 'Energy Resources: Indonesia,' [Online], [Retrieved 15 September 2014] http://www. worldenergy.org/data/resources/country/ indonesia/.

22.World Energy Council and Wyman, 0. (2013), 'World Energy Trilemma: Time to get real - the case for sustainable energy investment,' London: World Energy Council. 